\title{
Contribution of Agroforestry to Woody Species Diversity and Conservation in Ginir District, Southeast Ethiopia
}

\author{
Hirpa Abebe ${ }^{1, *}$, Zebene Asfaw ${ }^{2}$ \\ ${ }^{1}$ Oromia Agricultural Research Institute, Sinana Agricultural Research Center, Bale-Robe, Ethiopia \\ ${ }^{2}$ Wondo Genet College of Forestry and Natural Resources, Hawassa University, Shashamane, Ethiopia
}

Email address:

eirpa2000gmail.com (H. Abebe)

${ }^{*}$ Corresponding author

\section{To cite this article:}

Hirpa Abebe, Zebene Asfaw. Contribution of Agroforestry to Woody Species Diversity and Conservation in Ginir District, Southeast Ethiopia. American Journal of Environmental Protection. Vol. 10, No. 4, 2021, pp. 90-99. doi: 10.11648/j.ajep.20211004.13

Received: May 19, 2021; Accepted: July 8, 2021; Published: August 18, 2021

\begin{abstract}
As part of agriculture, agroforestry has great contribution as in-situ conservation for global biodiversity, because it contains different components. Besides, it improves the livelihoods of smallholder farmers by providing various products and services. However, there are limited scientific evidence and studies so far available on the roles of agroforestry to biodiversity conservation. Objective of the current study was to assess contribution of agroforestry on woody species diversity, conservation to sustain rural livelihoods at Ginir district, Southeast Ethiopia. Totally, six villages were selected based on their respective distance from the accessible roads and their agroforestry potential. A total of 70 sample HHs were randomly selected from the farmers full practiced agroforestry categories based on proportions of their representation. For the inventory of woody species, the lengths of farm boundary plantations were divided into $10 \mathrm{~m}$ sections. One section was selected for every $50 \mathrm{~m}$ of boundary length. A quadrant size of $10 \mathrm{~m} \times 5 \mathrm{~m}$ and $50 \mathrm{~m} \times 50 \mathrm{~m}$ were used for homegarden and parklands were conducted by taken one quadrant sample for each agroforestry practice from a house head farm. Both qualitative and quantitative data were collected and analyzed. Measurement of diversity needed to quantify and characterize agroforestry practices according to the degree of diversity and to examined the relationship of different agroforestry practices and woody species diversity at the village level and Kebeles. The result showed that 67 woody species belonging to 36 families and 58 genera were identified. Miomosoidceae was the most dominant family with $10(15 \%)$ species, followed by Myrtaceae family with $6(9 \%)$ species, Anacardiaceae and Rutaceae family accounted for 8 (12\%). In terms of species diversity, home gardens (2.47) were more diversified than parklands (2.33) and boundary plantation (1.98) in the overall study sites. Finally, it is concluded that Agroforestry were used to maintaining or as an option for maintaining native woody species to improve the rural community livelihoods of the rural farmers.
\end{abstract}

Keywords: Woody Species, Diversity, Conservation, Household, Agroforestry Practices

\section{Introduction}

Agriculture is the dominant sector of the Ethiopian economy. It provides about 52 percent of the country`s gross domestic product, 85 percent of its employment and 90 percent of its export earnings [2]. It is the main backbone of the economy and the major occupation of the Ethiopian population [3]. Rapid population growth and a long history of sedentary agriculture have changed the land use/land cover systems and caused environmental degradation in many developing countries including Ethiopia [4]. Majority of the people depend upon limited farmlands leading to further replacement of the forestland by agricultural land to feed the growing population. Agroforestry is dynamic, ecologicallybased natural resource management system that involves the integration of trees in agricultural landscape and rangeland diversifies and sustains production for increased social, economic and environmental benefits $[5,6]$.

To meet the current diverse people's requirements application of agroforestry, which is more advantageous than mono-cropping [7]. Because agroforestry can improve the livelihoods of smallholder farmers by providing various products and services. It generates high income and 
minimizes risks in cropping enterprises.

The major causes of woody species loss are linked to rapid human population growth rates and poverty. Woody species (trees and shrubs) are threatened in many different parts of the world and in our country. The density of woody species varies from place to place. Thus, woody species diversity can contribute to ecosystem productivity and sustainability under conditions of heterogeneity in species traits and environmental characteristics in agricultural landscapes [8]. The high diversity of species in homegardens, which combines crops, trees and animals having different uses and production cycles was considered as an essential component of sustainable agriculture because of the wide socioeconomic and ecological roles it plays in these systems.

Diversity means different things to different people. Most often in natural or agricultural systems, species counts (species richness) are providing as the measure of diversity. Continuing this logic, diversification means adding more species. Species diversity, however, is a function of the number of species, and the evenness in distribution of species' abundances [9]. The selective retention of woody species in agricultural landscapes is a traditional agroforestry practice in the smallholder sector of much of Africa $[10,11]$.

All forms of land use changes involving land resource utilization affect the biodiversity of an area directly or indirectly [12]. [13] indicated that $46 \%$ of the agricultural lands in the world have more than $10 \%$ of the tree cover, and $7.5 \%$ of the agricultural lands have tree cover of more than $50 \%$. This shows that AFPs are potential areas of conservation of biodiversity outside the forests and protected areas. The presence (and future) of the woody species in agricultural landscapes ultimately depends on the farmers who own and manage the land and the principal value of woody species in agricultural landscapes lies in their utility to resource-poor farmers [14].

Smallholder farmers in the study areas also depend on subsistence farming system leading to further degradation of the forest and soil resources. On the other hand, there are promising agroforestry practices in areas but the potential of these practices in woody species diversity conservation to improving the rural community livelihoods of farmers was not documented. Although agroforesry has been practiced in the low land particularly in Ginir district of Southeast Ethiopia. But there is no studies on its potential to woody species biodiversity conservation in the areas.

Objective of this study is to assess and identifying woody trees/shrubs species diversity in agroforestry practices and investigating their roles help to fully understand the potential of agroforestry practice in contributing to sustain woody species diversity conservation to rural community livelihoods improvement in Ginir District.

\section{Materials and Methods}

\subsection{Description of Study Sites}

The study was conduct in Ginir district, Bale zone, Oromiya Regional State of Ethiopia. Bale zone which is about $540 \mathrm{~km}$ from Addis Ababa and $140 \mathrm{~km}$ from zone capital (Robe). Ginir is geographically located between latitudes $7^{\circ} 12^{\prime} 00^{\prime \prime}$ to $7^{\circ} 2^{\prime} 00^{\prime \prime} \mathrm{N}$ and $40^{\circ} 40^{\prime} 00^{\prime \prime}$ to $40^{\circ} 56^{\prime} 00^{\prime \prime} \mathrm{E}$ longitude (Figure 1). The topography of the area is generally characterized by flat, gentle slope to undulating terrain, with an altitudinal range of 1184 to 2363 m.a.s.l. It covers an area of $238,422.37$ hectares and the mean annual temperature is about $23^{\circ} \mathrm{C}$. The area is characterized by a bimodal rainfall pattern and distribution, and average annual rainfall is 900 $\mathrm{mm}$ [15].

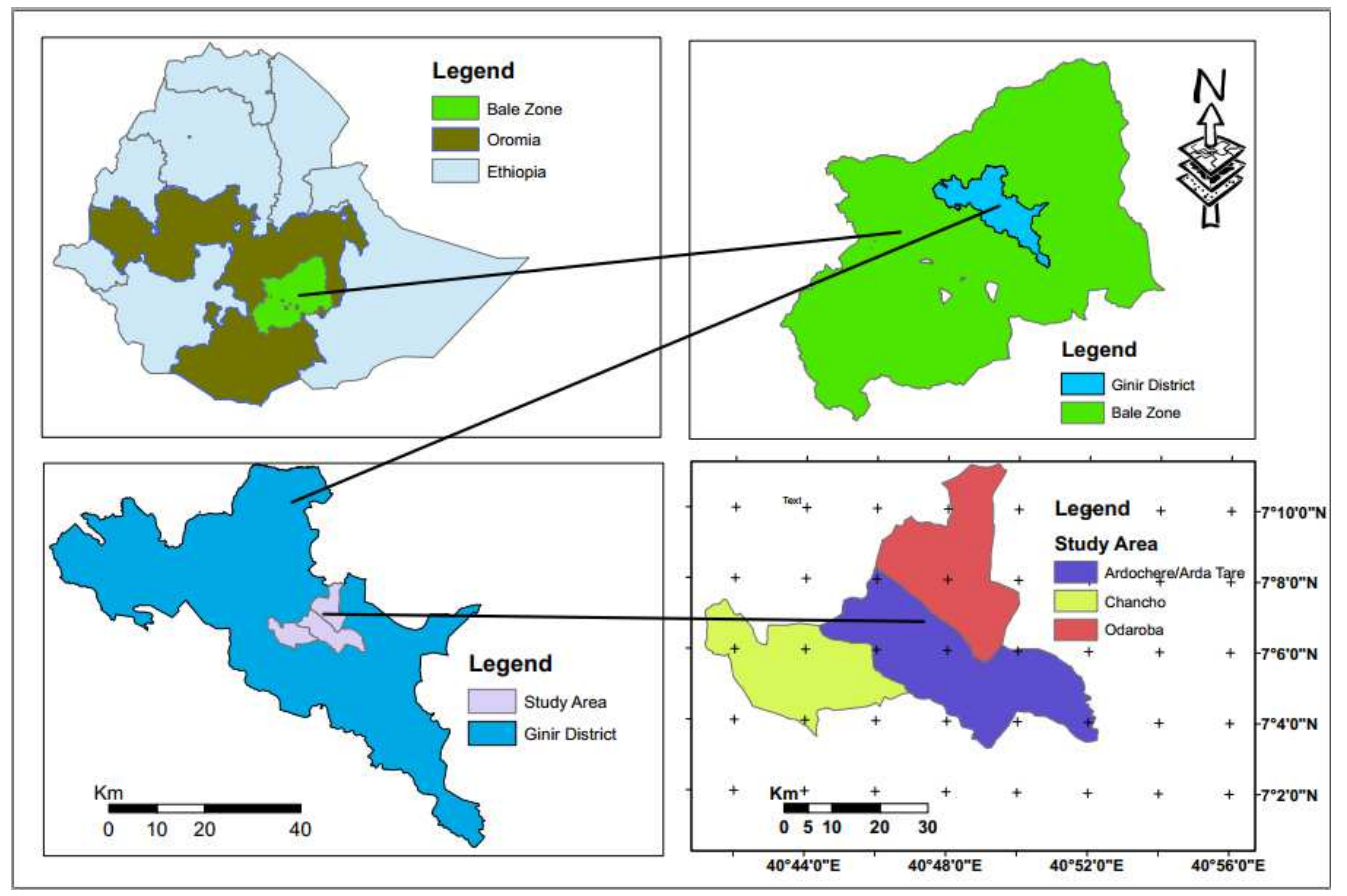

Figure 1. Map of the study area. 


\subsection{Study Site Selection}

Ginir district was selected purposively among the 17 districts of the zone due to the presence of agroforestry practices. A reconnaissance survey was conducted with agricultural officer and DA of different Kebeles, to obtain good insights road accessibility and the presences of AFPs. Accordingly, three kebeles, namely, Canco, Odaroba and Arada tare were identified and selected purposefully based on the presence of agroforestry practice, better accessibility among the 29 Kebeles' in the district. Within each kebele, two villages were randomly selected.

\subsection{Woody Species Inventory}

Woody species such as trees and shrubs, including woody climbers, were considered in this study. In the present study, a tree was defined as single-stemmed woody perennial with diameter at breast height $(1.3 \mathrm{~m}$; dbh $\leq 2.5$ $\mathrm{cm}$ and height $\leq 1.5 \mathrm{~m}$. A shrub was defined as a woody perennial with multiple-stems $\leq 2.5 \mathrm{~cm}$ dbh and height $\leq 1.5$ $\mathrm{m}$, without a dominant stem [16]. Inventory of tree/shrub species was done out on farms of sampled households. For species richness calculations, all tree and shrub species on the farms were recorded following an approach used by [17]. For this inventory, woody species with $\mathrm{dbh} \geq 5 \mathrm{~cm}$ (at $1.3 \mathrm{~m}$ height) was measured using caliper and/or diameter tape. For trees /shrubs forking at or just above $1.3 \mathrm{~m}$, both stems were measured above the fork and the average was taken or treated as one tree. For trees /shrubs forking below $1.3 \mathrm{~m}$, each stem measured and treated as two separate trees. For woody species or trees/shrubs with dbh below $5 \mathrm{~cm}$, only stem count made to know abundance [18]. For the inventory of boundary plantations, [19] approaches were used. The length of boundary plantations was divided into $10 \mathrm{~m}$ sections. One section was selected for every $50 \mathrm{~m}$ of boundary length. When the length is less than $10 \mathrm{~m}$, the actual length is considered. Inventory of homegarden trees, trees on parkland $\mathrm{AF}$ and grazing lands were conducted by taking one quadrant sample for each AFP from a HH farm based the approaches following [1] with some adjustments. Thus, for this study, a quadrant size of $10 \times 5 \mathrm{~m}$ and $50 \times 50 \mathrm{~m}$ were used for homegarden and AF parklands, respectively.

For the identification of the farm and the local names of woody tree/shrub species on the farm, the owners of the land were involved in the counting and identification of species. For species identification, local names (vernacular names) adopted by framers and different reference materials are used to identify them and their botanical name arranged and recorded $[20,21]$.

\subsection{Data Analysis}

Both qualitative and quantitative data were collected and analyzed. The qualitative data were collected and analyzed partially during the process of data collection, to be able immediately to identify gaps was filled through subsequent data collection.
The quantitative data are first summarized, tallied and coded and processed, and was analyzed by means of Statistical Package for Social Sciences (SPSS) version 16 software and with Microsoft Excel. By means of descriptive statistics, the mean, range, frequencies, percentages, minimum as well as maximum values of variables were calculate.

Measurement of diversity needed to quantify according to the degree of diversity and to examine the relationship of different agroforestry practices and woody species diversity at the village level and KAs. Based on individual farms, the mean numbers of woody tree/shrub species per AFPs was estimate for each practice and at village level and KAs. The results from the diversity indices were further subject to ANOVA. Moreover, variation in the composition of species among the AFPs was determined by computing Beta diversity $(\beta)$ and one-way ANOVA used to analyze the importance of AFPs.

\subsection{Woody Species Diversity Measurements}

\subsubsection{Diversity Indices}

Measurement of diversity is needed to quantify and characterize AFPs according to the woody species diversity at the village level and KAs. Based on individual farms, the mean numbers of tree/shrub species per AFPs were estimated for each village and Kebeles. Although several quantitative descriptions are available for characterizing species diversity, the Shannon-Wiener and Shannon equitability (Evenness) [9, 22] are commonly used and considered in this study. Richness and diversity of each AFP types were calculated as the number species, Shannon and evenness indices. In addition to this importance value index (IVI) was calculated to demonstrate the importance of individual tree/shrub species on farmland. The results from the diversity indices were further subjected to ANOVA.

\subsubsection{Shannon-Wiener Index of Diversity}

In species diversity study, two components are important: richness and evenness. The species richness refers to the number of species per farm while evenness refers to their relative abundance. To determine species richness of each farm, species index (S), which is simply the total number of tree/shrub species on a farm were calculated. However, this index does not indicate the relative proportion or abundance of a particular species on the farm. Hence models that incorporate both evenness and richness of relative abundance are required. Shannon index and Evenness measures (E) which are commonly used tools for these purposes [9] were calculated. Shannon diversity index $\left(\mathrm{H}^{\prime}\right)$ is high when the relative abundance of the different species in the sample is even, and decreases when few species are more abundant than the others. It is based on the theory that when there are many species with even proportions, the uncertainty that a randomly selected individual belongs to a certain species increases and thus the diversity. It relates proportional weight of the number of individuals per species to the total number 
of individuals for all species [22].

The Shannon-diversity index $\left(\mathrm{H}^{\prime}\right)$ calculated, to analyse the diversity of tree/shrub species per farm and it was calculated as follows:

$$
\mathrm{H}^{\prime}=\sum_{i=1}^{s} P_{i} \operatorname{In} P_{i}
$$

$\mathrm{Pi}=$ the proportion of individuals or abundance of the $\mathrm{i}^{\text {th }}$ species expressed as proportion of the total abundance, Inpi =natural logarithm of pi and $\mathrm{S}=$ the number of species, $\mathrm{i}=1$, $2,3 \ldots$ s.

\subsubsection{Evenness (Equitability) Index}

Evenness (Shannon equitability) index (E) was calculated as follows to estimate the homogeneous distribution of tree species on farms.

$$
\mathrm{E}=\frac{\mathrm{H}^{\prime}}{H \max }=\frac{\mathrm{H}^{\prime}}{\operatorname{InS}}=\frac{\sum_{i=1}^{S} \text { piInpi }}{\operatorname{InS}}
$$

Where $\mathrm{S}=$ the number of species, $\mathrm{Pi}=$ proportion of individuals of the $i^{\text {th }}$ species or the abundance of the $i^{\text {th }}$ species expressed as proportion of the total abundance. Thus, the measure of evenness (E) is the ratio of observed diversity to maximum possible diversity. $\mathrm{E}$ has values between 0 and 1 , where 1 represents a situation in which all species are equally abundant. From these calculations, species richness and heterogeneity as well as density of trees/shrubs were characterized for each farm. The values obtained, were then compared across the AFPs to test for the differences in species richness and evenness of trees.

\subsubsection{Similarity Indices (Ss)}

Similarity indices measure the degree to which the species composition of different systems is alike. Many measures exist for the assessment of similarity or dissimilarity between vegetation samples or quadrates. The Sorensen similarity coefficient is applied to qualitative data and is widely used because it gives more weight to the species that are common to the samples rather than to those that only occur in either sample [22].

The Sorensen coefficient of similarity (Ss) was given by the formula:

$$
S S=\frac{2 a}{2 a+b+c}
$$

where, Ss $=$ Sorensen similarity coefficient, $a=$ number of species common to both samples, $b=$ number of species in sample 1 and $\mathrm{c}=$ number of species in sample 2 .

\subsubsection{Multiple Site Similarity Indices (Ss)}

The similarity of woody species diversity among the threeland use types were analyzed by using a multiple-site similarity index using a multiple-site similarity measure. This method was used because similarity measures have restriction that is limited to pair wise comparisons even in a multiple-site study and this method overcomes this problem of covariance between pair wise similarities in a multiple site study [23].

This index was defined as:

$$
\text { MSSI }=\frac{a b+a c+b c-a b c}{a+b+c}
$$

Where, MSSI $=$ multiple site similarity index

$\mathrm{a}=$ number of species site/community $1, \mathrm{~b}=$ number of species found in site/community $2, \mathrm{c}=$ number of species found in site/community $3, a b=$ number of species common to site/community 1 and 2 system, ac $=$ number of species common to site/community 1 and 3 system, bc = number of species common to site/community 2 and 3 system, abc $=$ the number of species found in the three sites/community systems.

\subsubsection{Importance Value Index (IVI)}

The IVI indicates the importance of individual tree/shrub species in the land-use systems and was calculated with three components [22] as follows;

$$
\begin{gathered}
\text { Relativefrequency }=\frac{\text { Frequenceofaspecies }}{\text { Sumoffrequencyofallspcies }} * 100 \% \\
\text { Relative density }=\frac{\text { Numberofindividualsofaspecies }}{\text { Totalnumberofindividualsofallspecies }} * 100 \% \\
\text { Relative dominance }=\frac{\text { Dominanceofaspecies }}{\text { Totaldominanceofallspecies }} * 100 \% \\
\text { IVI }=\text { Relative (density }+ \text { frequency }+ \text { dominance })
\end{gathered}
$$

\section{Results and Discussions}

\subsection{Woody Species Diversity}

\subsubsection{Woody Species Richness}

Diversity used to compute for species richness and species evenness of the plant community types in the vegetation. The result showed that a total of 67 woody species belonging to 36 families and 58 genera were identified in the study area. The dominant families are Miomosoidceae (10), Myrtaceae
(6), Anacardiaceae (4), Rutaceae (4) Papilionoideae (3) and Meliaceae (3) which accounts about $45 \%$ of the total woody plant species. This study result was like the result report by [24] in south-eastern rift valley escarpment of Ethiopia, [25] in Jimma, [26] in northwestern Ethiopia and [27] in Gununo watershed at Wolayitta zone.

Among the total identified woody species, 60 were found in homegardens, 45 in parklands, and 39 in farm boundary plantations. The highest numbers of woody species were identified in homegardens than other agroforestry practices, which go with the findings of $[26,28,29]$ who reported that 
higher number of woody species were present in homegardens than other land use types. From the total 67 woody tree/shrub species identified and recorded at the study area, 58, 49 and 46 were found at Odaroba, Aradachire and Canco kebeles, respectively. Farmers managed both exotic and native woody trees/shrubs. Out of identified woody species, 75\% was indigenous and the rest was exotic species. Comparatively highest numbers of indigenous tree/shrub species were recorded at Aradachire Kebele as compared to other Kebeles (Figure 2). This result is alike as a study result done by [30] who gathered 55 woody species belonging to 31 families, where 47 of these species were indigenous and the rest exotics. Conversely, in south-west Uganda of Igazi highland, for instance, [11] found plantation with $69 \%$ exotic and $31 \%$ indigenous trees but the study conducted at different places. High number of, indigenous tree/shrub species in this study were relating might be to farmers' effort of maintaining the already existing species, planting and function of either household preference or best fit to the given ecology/climate.

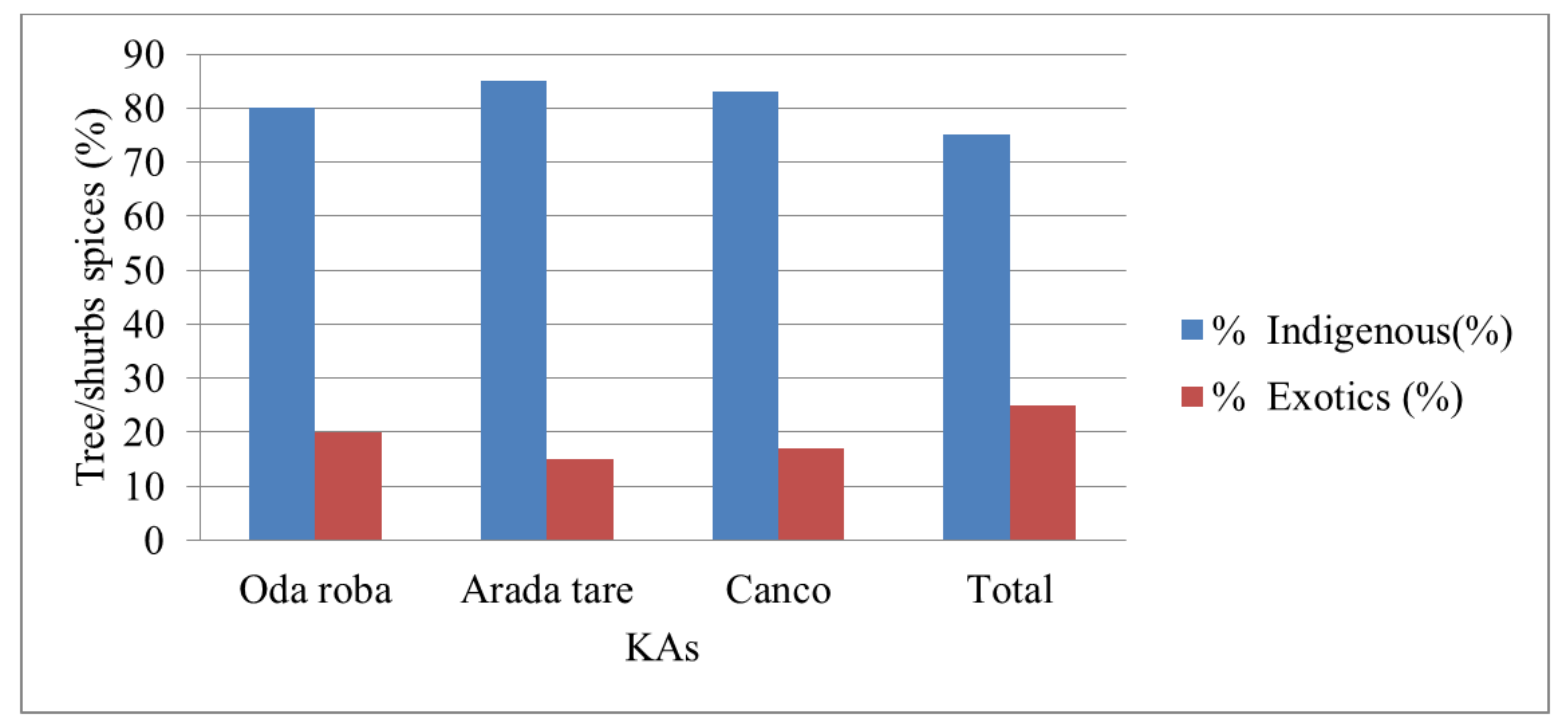

Figure 2. Percentage of indigenous and exotic tree/shrub species within kebeles at the study area.

From the identified woody species, trees and shrubs accounted for $57 \%$ and $39 \%$ respectively, and the rest were climber and others. This study output is a like with the finding of $[29,28,31,32]$, who reported that the identified woody species were dominated by trees but the research conducted at different places.

Woody species were different among Kebeles and villages in the parkland. Others study scholars reported by [33] in
Tigray Region, [28] in South-Central Ethiopia and lower than study result identified by [34] in Southern Ethiopia. According to total frequencies distribution of all woody species of Coffea arabica, Eucalyptus camaldulensis, Chata edulis, Cordia africana, Croton macrostachyus, Mangifera indica, Albizia species and Persea americana were the most frequent, which were the top 19 dominant woody species constituting about $68 \%$ of the total (figure 3 ).

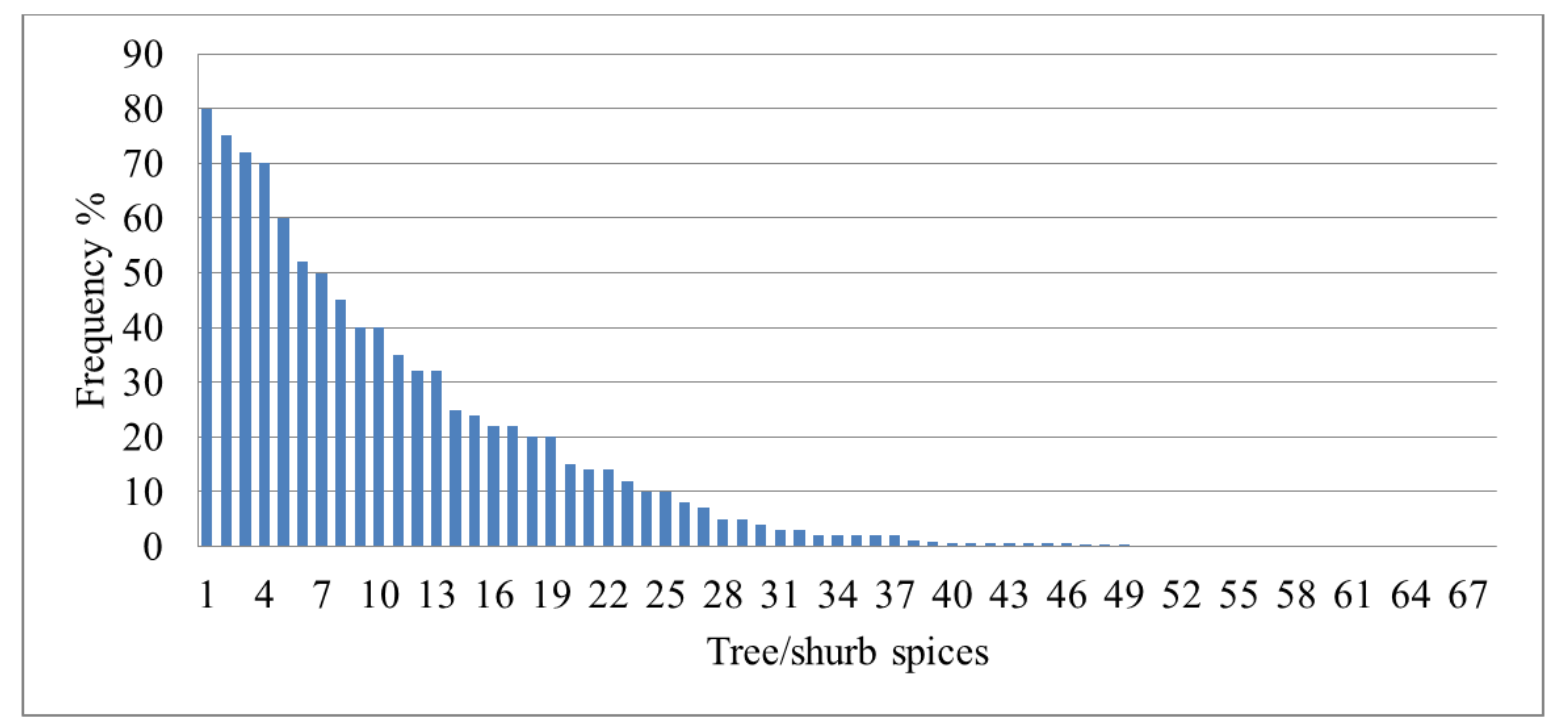

Figure 3. Frequency distribution of tree/shrub species on sampled HH farms $(N=70)$. 
Table 1. Legend of Figure 3 (frequency distribution of tree/shrub species of the study areas).

\begin{tabular}{|c|c|c|c|c|c|}
\hline S/no & Species name & S/no & Species name & S/no & Species name \\
\hline 1 & Coffea arabica & 16 & Casimiroa edulis & 31 & Balanites aegyptiaca \\
\hline 2 & E. camaldulensis & 17 & Rubus ellipticus & 32 & Rhamnus prinoides \\
\hline 3 & Catha edulis & 18 & Euphorbia tirucalli & 33 & Grewia villosa \\
\hline 4 & Cordia africana & 19 & Acacia oerfota & 34 & Cupressus lusitanica \\
\hline 5 & Acacia brevispica & 20 & Ehretia cymosa & 35 & Schinus molle \\
\hline 6 & Croton macrostachyus & 21 & Acacia abyssinica & 36 & Erythrina abyssinica \\
\hline 7 & Mangifera indica & 22 & A. sieberiana & 37 & Sesbania sesban \\
\hline 9 & Eucalyptus globules & 24 & Annona senegalensis & 39 & Buddleja polystachya \\
\hline 10 & Persea americana & 25 & Carissa edulis & 40 & Embelias chimperi \\
\hline 11 & Albizia schimperiana & 26 & Citrus aurantifolia & 41 & Grevillea robusta \\
\hline 12 & Psidlum guajava & 27 & Justicias chimperiana & 42 & Azadirachta indica \\
\hline 13 & Jatropha acerifolia & 28 & Juniperus procera & 43 & Callistemon citrnus \\
\hline 14 & A. toritilis & 29 & Celtis africana & 44 & Rhusnatalensis \\
\hline 15 & Acacia bussei & 30 & Vernonia amygdalin, & 45 & Ilexmitis.. etc \\
\hline
\end{tabular}

Related to species richness Coffea arabica, Mangifera indica, Persea americana and Albiza species are frequently observed in homegardens than other agrofoestry practices. The planting of various exotic and native woody species in the homegardens leads to higher species richness. The introduced woody species include exotic species, different fruit trees, cash crops and some species which were brought from the adjacent KAs and other localities. In general, this study result showed that the average or mean number of woody species of the sampled households at the study agroforestry practices in all Kebeles were 11, 3.13 and 1.9 in home-gardens, parklands and farm boundary, respectively. There were no significant difference in mean number of woody species among the Kebeles and villages in the same agroforestry practices (Table 1).

Table 2. Mean \pm std, number of species of agroforestry practices at the study Kebeles and villages of Ginir district, Southeast Ethiopia.

\begin{tabular}{|c|c|c|c|c|}
\hline \multirow{3}{*}{ S/no } & \multirow{3}{*}{ Kebele/PAs } & \multicolumn{3}{|l|}{ Agroforestrypractices } \\
\hline & & Home-garden $(n=70)$ & park land $(n=61)$ & Farmboundary $(n=64)$ \\
\hline & & Mean \pm std & Mean \pm std & Mean \pm std \\
\hline \multirow[t]{3}{*}{1} & Odaroba & $10.00 \pm 2.28$ & $2.70 \pm 1.05$ & $1.93 \pm 0.70$ \\
\hline & Village/zone 1 & $11.80 \pm 2.99$ & $2.44 \pm 0.53$ & $2.00 \pm 0.71$ \\
\hline & Village/zone 3 & $12.22 \pm 1.4$ & $3.00 \pm 1.55$ & $1.83 \pm 0.75$ \\
\hline \multirow[t]{3}{*}{2} & Arada tare & $10.36 \pm 2.68$ & $3.00 \pm 1.1$ & $1.70 \pm 0.67$ \\
\hline & Village/zone 1 & $10.92 \pm 3.15$ & $2.72 \pm 0.65$ & $1.80 \pm 0.75$ \\
\hline & Village/zone 2 & $9.56 \pm 1.7$ & $3.40 \pm 1.41$ & $1.50 \pm 0.53$ \\
\hline \multirow[t]{4}{*}{3} & Canco & $10.57 \pm 1.9$ & $3.70 \pm 1.18$ & $1.90 \pm 0.72$ \\
\hline & Village/zone 1 & $12.50 \pm 2.2$ & $3.85 \pm 1.34$ & $2.13 \pm 0.64$ \\
\hline & Village/zone 2 & $10.60 \pm 1.65$ & $3.50 \pm 1$ & $1.75 \pm 0.75$ \\
\hline & Over all mean & $11.00 \pm 2.3$ & $3.13 \pm 1.1$ & $1.90 \pm 0.70$ \\
\hline
\end{tabular}

Table 3. Shannon index $\left(H^{\prime}\right)$ and Evenness (E) of AFPs at the study villages and kebeles of HHs of the study sites.

\begin{tabular}{|c|c|c|c|c|c|c|c|c|c|}
\hline \multirow{3}{*}{ № } & \multirow{3}{*}{ Kebele/Villages } & \multicolumn{8}{|c|}{ AFPs } \\
\hline & & \multicolumn{2}{|c|}{ Homegarden } & \multicolumn{2}{|c|}{ Parkland } & \multicolumn{2}{|c|}{ Farm boundary } & \multicolumn{2}{|c|}{ Over all } \\
\hline & & $\mathrm{H}^{\prime}$ & $\mathbf{E}$ & $\mathbf{H}^{\prime}$ & $\mathbf{E}$ & $\mathbf{H}^{\prime}$ & $\mathbf{E}$ & $\mathrm{H}^{\prime}$ & $\mathbf{E}$ \\
\hline \multirow[t]{3}{*}{1} & Odaroba & 2.98 & 0.75 & 2.78 & 0.76 & 2.4 & 0.68 & 2.72 & 0.73 \\
\hline & Village/zone 1 & 2.14 & 0.67 & 1.48 & 0.51 & 2 & 0.72 & & \\
\hline & Village/zone 3 & 2.1 & 0.63 & 1.65 & 0.54 & 1.4 & 0.48 & & \\
\hline \multirow[t]{3}{*}{2} & Arada tare & 2.78 & 0.74 & 2.81 & 0.80 & 1.8 & 0.54 & 2.47 & 0.69 \\
\hline & Village/zone 1 & 2.5 & 0.77 & 2.3 & 0.85 & 2.2 & 0.86 & & \\
\hline & Village/zone 2 & 1.64 & 0.49 & 1.9 & 0.66 & 2 & 0.72 & & \\
\hline \multirow[t]{4}{*}{3} & Canco & 2.85 & 0.77 & 2.9 & 0.85 & 2.2 & 0.67 & 2.85 & 0.77 \\
\hline & Village/zone 1 & 2.6 & 0.90 & 2.63 & 0.60 & 1.85 & 0.74 & & \\
\hline & Village/zone 2 & 2.1 & 0.67 & 2.5 & 0.88 & 2.3 & 0.85 & & \\
\hline & Over all & 2.87 & 0.75 & 2.83 & 0.80 & 2.33 & 0.63 & 2.67 & 0.73 \\
\hline
\end{tabular}

**Shannon index (H'), Evenness (E) and Agroforestry practices (AFPs).

\subsubsection{Mean Shannon Species Diversity Index and Evenness}

The overall mean Shannon- wiener diversity and evenness of woody species in the study sites were 2.7 and 0.73 respectively. Mean Shannon species diversity of homegarden, parkland, farm boundary plantations were $2.47,2.33$ and 1.98 , respectively. The species diversity of homegardens in each site were higher than parklands and farm boundary plantations of the study area (Table 2). The observed trend might be due to the difference in land use types and functions 
of woody species. The result indicated that the mean species diversity was higher in Canco $\left(\mathrm{H}^{\prime}=2.52\right)$ followed by Odaroba $\left(\mathrm{H}^{\prime}=2.41\right)$ and comparatively lower mean species diversity recorded in Arda tare Kebele $\left(\mathrm{H}^{\prime}=2.35\right)$ and mean species evenness ranged between 0.78 at Canco and 0.67 at Odaroba Kebele in the homegarden agroforestry practices.

The maximum mean Shannon diversity $\left(\mathrm{H}^{\prime}=2.98\right)$ was recorded at village-1 of Odaroba and the minimum $\left(\mathrm{H}^{\prime}=1.64\right)$ at Village-2 of Arda tare kebele among homegarden agroforestry practices of the study sites. The overall mean Shannon- wiener diversity and evenness of woody trees and shrubs species in the study sites of homegardens were 2.47 and 0.74 , respectively. Generally, this study showed that species richness, diversity and evenness varied with land use type or agroforestry practices, kebeles and villages, which confirmed agroforestry, were basic and important home for woody species conservation. [35-37, 28, $26,29,33]$ reported that homegardens were more diversified than others.

A Parkland practice involves the growing of trees and shrubs in wide spaces in croplands. Dispersed trees grown in farmlands characterize a large part of the Ethiopian agricultural landscape. Trees would be grown in a scattered form over a crop field, usually to minimize impact on the companion crop. The overall mean Shannon- wiener diversity and evenness of woody trees and shrubs species in the study sites of parklands were 2.33 and 0.68 respectively. The maximum mean Shannon diversity $\left(\mathrm{H}^{\prime}=2.83\right)$ was recorded at village 1 of Canco and the minimum $\left(\mathrm{H}^{\prime}=1.48\right)$ at
Village 1 of Odaroba Kebele among parklands agroforestry practices of the study sites.

In parklands, the high mean species diversity was recorded in Canco $\left(\mathrm{H}^{\prime}=2.65\right)$ than Arda tare $\left(\mathrm{H}^{\prime}=2.34\right)$ and Odaroba $\left(\mathrm{H}^{\prime}=1.97\right)$ kebeles and the evenness index of woody species were $0.78,0.77$ and 0.60 respectively (Tables 2, 3 and 4). Various studies on woody species diversity of parkland Agroforestry report different diversity from different part of the regions [38, 28, 33, 26].

In general farm boundary plantations mean Shannon diversity of the study areas shown on (Tables 2, 3 and 4). This result indicated that the mean species diversity was higher in Canco $\left(\mathrm{H}^{\prime}=2.12\right)$ followed by Arada tare $\left(\mathrm{H}^{\prime}=1.95\right)$ and the comparatively lower mean species diversity recorded in odarobaKebele $\left(\mathrm{H}^{\prime}=1.93\right)$ and mean species evenness ranged between 0.75 at Canco and 0.63 at Odaroba kebele in the farm boundary agroforestry practices of study sites. The maximum mean Shannon diversity $\left(\mathrm{H}^{\prime}=2.40\right)$ was recorded at village- 1 of Odaroba and the minimum $\left(\mathrm{H}^{\prime}=1.40\right)$ at Village of the same Kebele among farm boundary agroforestry practices of the study sites.

The overall mean Shannon- wiener diversity and evenness of woody trees and shrubs species in the study sites of homegardens were 1.98 and 0.80 respectively. General the study find out mean values indicate significant difference $(\mathrm{P}<0.05)$ among Kebeles and villages in both woody species diversity and evenness in the same agroforestry practice of all practices of the study sites (Tables 2, 3 and 4).

Table 4. Mean Shannon Diversity Index $\left(H^{\prime}\right)$ in agroforestry practices with in a study Kebeles.

\begin{tabular}{|c|c|c|c|c|c|c|c|c|c|c|c|c|}
\hline \multirow{2}{*}{ PAs } & \multicolumn{4}{|c|}{ H of HG } & \multicolumn{4}{|c|}{$H^{\prime}$ of $P L$} & \multicolumn{4}{|c|}{ H of FB } \\
\hline & Mini & Maxi & Mean & Std. & Mini & Maxi & Mean & Std. & Mini & Maxi & Mean & Std. \\
\hline Odaroba & 2.10 & 2.98 & $2.41 \mathrm{~b}$ & 0.50 & 1.48 & 2.78 & $1.97 \mathrm{c}$ & 0.71 & 1.40 & 2.40 & $1.93 \mathrm{c}$ & 0.50 \\
\hline Aradatare & 1.64 & 2.78 & $2.35 \mathrm{c}$ & 0.59 & 1.90 & 2.81 & $2.34 \mathrm{~b}$ & 0.46 & 1.80 & 2.20 & $1.95 \mathrm{~b}$ & 0.22 \\
\hline Canco & 2.10 & 2.85 & $2.52 \mathrm{a}$ & 0.38 & 2.50 & 2.83 & $2.65 \mathrm{a}$ & 0.17 & 1.85 & 2.30 & $2.12 \mathrm{a}$ & 0.24 \\
\hline Total & 1.64 & 2.98 & 2.47 & 0.44 & 1.48 & 2.83 & 2.33 & 0.53 & 1.40 & 2.40 & 1.98 & 0.31 \\
\hline
\end{tabular}

** Different letters following in mean values indicate significant difference $(\mathrm{P}<0.05)$ among Kebeles and villages in both woody species diversity and evenness in the same agroforestry practices with in the column.

Table 5. Mean Shannon Diversity Evenness (E) in study Kebeles among agroforestry practices.

\begin{tabular}{|c|c|c|c|c|c|c|c|c|c|c|c|c|}
\hline AFPs & HG & & & & PL & & & & FB & & & \\
\hline & Min. & Max. & Mean & Std. Dev. & Min. & Max. & Mean & Std. Dev. & Min. & Max. & Mean & Std. Dev. \\
\hline Odaroba & 0.63 & 0.75 & 0.68 & 0.06 & 0.51 & 0.76 & 0.60 & 0.14 & 0.48 & 0.72 & 0.63 & 0.13 \\
\hline Aradatare & 0.49 & 0.77 & 0.67 & 0.15 & 0.66 & 0.85 & 0.77 & 0.10 & 0.54 & 0.86 & 0.71 & 0.16 \\
\hline Canco & 0.67 & 0.90 & 0.78 & 0.12 & 0.60 & 0.88 & 0.78 & 0.15 & 0.67 & 0.85 & 0.75 & 0.09 \\
\hline Total & 0.49 & 0.90 & 0.74 & 0.11 & 0.51 & 0.88 & 0.68 & 0.14 & 0.48 & 0.86 & 0.80 & 0.13 \\
\hline
\end{tabular}

\subsection{Similarity in Species Composition}

Similarity index of the study area ranged from $0.43-0.60$ (Table 5). Based on the presence and absence of woody species in the sampled plots /AFPs. There are similarities in plant species composition among the AFPs. Canco and Odaroba in district had the more similarity index, which means that they shared $47 \%$ of the woody plant species in common. On the other hand, Arada tare and Canco relatively had the least similarity index, which means that they share $43 \%$ of the plant species. The multiple-site similarity index of Canco, Odaroba and Arada tare kebeles found to be $60 \%$ or about $60 \%$ species were overlapping between the three kebeles. This indicates that, the three study Kebeles have high overlapping species with each Kebeles (Table 6).

The similarities in woody species composition were compared among the agroforestry practices/land uses. Based on the presence and absence of woody species in the sampled plots /AFPs. The highest similarity in woody species compositions $(45 \%)$ was recorded between homegarden and parkland, while the lowest $(39 \%)$ was recorded between parkland and farm boundary and $43 \%$ similarity observed 
between homegarden and Farm boundary. The multiple-site similarity index of parkland, farm boundary and homegarden agroforestry practices found to be $57 \%$. This indicates that, the three land uses have high overlapping species with each other. Syzygium guineense, Afrocarpus falcatus, Croton macrostachyus, Ocoteakenyensis and Polyscias ferruginea woody species were common to homegarden and parkland. Whereas, Croton macrostachyus, S. guineense and Ehretia cymosa were common for homegarden and farm boundary. Syzygium guineense, Croton macrostachyus, Persea americana, Psidium guajava and Coffea arabica are species commonly grown both in the parkland and farm boundary. About $57 \%$ species were overlapping between the homegarden, parkland and farm boundary. Woody species retained on parklands and homegardens are remnants of the natural vegetation which has once covered and some of the woody species planted by farmers were also native to the area and which species preferred by the farmers.

Table 6. Similarity index of woody species among the agroforestry practices.

\begin{tabular}{lll}
\hline № & Agroforestry practices & Similarity (\%) \\
\hline 1 & Parkland Vs homegarden & 45 \\
2 & Parkland Vs farm boundary & 39 \\
3 & Homegarden Vs farm boundary & 43 \\
4 & Parkland Vs homegarden Vs farm boundary & 57 \\
\hline
\end{tabular}

Table 7. Similarity index of woody species among Kebeles at the study areas.

\begin{tabular}{lll}
\hline № & PAs/Kebeles & Similarity (\%) \\
\hline 1 & CancoVs Arada tare & 43 \\
2 & CancoVs Odaroba & 47 \\
3 & Arada tare Vs Odaroba & 45 \\
4 & CancoVs Arada tare Vs Odaroba & 60 \\
\hline
\end{tabular}

\subsection{Mean Importance Value Index (IVI)}

To evaluate ecological and other benefits of each woody species recorded in the study site, their importance value index (IVI) was calculated and presented in (Table 7). The IVI of woody species recorded indicates the importance of individual woody species in the land use systems, which were associated with farmers' species preferences and objectives. The interests of farmers for selection of species are linked with species market demand and service value. IVI is a composite index based on the relative measures of species frequency, abundance and dominance [22]. The highest IVI woody species in the overall study sites according to their importance were Coffee arabica, E. camaldulensis, Catha edulis, Cordia africana, Acacia brevispica, Croton macrostachyus, Mangifera indica, Albizia gummifera,. Eucalyptus globules, Persea americana, Albizia schimperiana, Psidlum guajava, Jatropha acerifolia, A. toritilis, have larger relative frequency values and contributed about $85 \%$ to the highest IVI.

The major highest and top six of IVI in home garden were coffea arabica, Catha edulis, Cordia africana, Croton macrostachyus, Mangifera indica, Perse aamericana and Albizia gummifera were the top important species among the 60 woody species that were recorded in the homegarden agroforestry practices of the study sites. The current result agrees with [39] who reported IVI value determined by density, frequency and relative dominance, [40] also revealed that species with the greatest importance values were the most dominant of particular vegetation. And this finding is in line with a similar study reported by [31] in Jabithenan district, Northwest Ethiopia.

In the study parklands Croton macrostachyus, Cordia africana, Juneprous porcera, Acacia abyssinica, Casimiroa edulis, Mangiferaindica, Catha edulis and Vernonia amygdalina were the top important species among the 45 woody species that were recorded in parklands agroforestry practices and land use system of the study sites. In study farm boundaries species like Rosa abyssinica, E. camaldulensis, Eucalyptus globulus, Psidlum guajava, Justicia schimperiana, Vernonia amygdalina and Jatropha acerifolia were the top important species among the 39 species that were recorded in farm boundary agroforestry practices and land use system of the study sites.

\section{Conclusions}

1) Farmers through their local knowledge will enabling to recognize the woody tree/shrub species diversity by identifying existences on farmland and retain them according to the spaces available and their compatibility with agricultural crops and household needs.

2) Homegarden, Parkland and farm boundary plantation practices were the major agroforestry practices identified and recorded. Homegardens are more diverse and multilayered component than the rest because it is most preferred, introduced and planted/retained in AFPs.

3) Miomosoidceae was the most dominate family followed by Myrtaceae due to their contribution to the farmers and the results confirm that the AFPs play a major role in conservation of native woody species.

\section{Recommendations}

Based on the findings, the following are recommended:

1) To overcome the decline of woody species with increasing cultivation periods of land, some woody species which are highly valuable for the farmers and that has no negative effect on the productivity of the crops has to be introduced according tothe preferences of the farmers and agro-ecology fitness or adaptation of the species.

2) Farmers' indigenous knowledge and experiences shall be incorporated in the whole processes (planning, implementation,....) but this knowledge has not been well supported scientifically and encouraged and support them through extension services concerning management of woody species and others.

3) Gov't should encourage AFPs than focusing only on increasing crop production per unit area due to more advantages of agroforestry.

4) Further studies should be carried out in multidisciplinary approaches in order to contribute for 
holistic and sustainable development, e.g. Detail economic analysis on the components of agroforestry.

\section{Acknowledgements}

This work was financed and supported by Oromia Agricultural Research Institute, Sinana Agricultural Research center.

\section{References}

[1] Nikiema, A., van der Maesen, L. J. G. \& Hall John, B. (2005). Woody species composition of Sudan savanna parklands in relation to rural land use gradients in Burkina Faso. PhD Thesis, Wageningen University, Wageningen, $102 \mathrm{pp}$.

[2] Badege, B., Sisay, A., Efrem, B., Haile Selassie, B., \& Michael, W. (2006). Agricultural and rural development in Ethiopia summary and recommendations, International conference on a development strategy of Horn of Africa rural and agricultural development panel organized by the Africa program, the University of Texas, October 20-22, 2006.

[3] Ministry of Mines and Energy (MoME). (2003). Geological Survey of Ethiopia: Industrial Minerals and Rocks Resource Potentials of Ethiopia, Addis Ababa.

[4] Feoli, E., Gallizia, L. V. \& Woldu, Z. (2002). Processes of Environmental Degradation and Opportunities for Rehabilitation in Adwa, Northern Ethiopia. Landscape Ecology 17: 315-32.

[5] Duguma, L. A. \& Hager, H. (2010). Woody plants diversity and possession, and their future prospects in small-scale tree and shrub growing in agricultural landscapes in central highlands of Ethiopia. Small-Scale Forestry, 9 (2), 153-174. doi: 10.1007/s11842-009-9108-0.

[6] Kiptot, E.\& S. Franzel. (2011). Gender and Agroforestry in Africa: Are women participating? World Agroforestry Centre, Nairobi.

[7] McNeely J. A. \&Scroth G., (2006). Agroforestry and biodiversity conservation - traditional practices, present dynamics and lessons for the future. Biodiversity Conservation, 15: 549-554.

[8] Kindt, R., Simons, A. J. \&Damme, P. V. (2004). Do Farm Characteristics Explain Differences in Tree Species Diversity among Western Kenyan Farms? Agroforestry Systems 63: 63 - 74.

[9] Magurran, A. E. (1988). Ecological diversity and its measurement. London: Croom Helm Limited, 179 pp.

[10] Ingram, J. (1990). The role of trees in maintaining and improving soil productivity - a review of the literature. In: Prinsley, R. T. (Ed.). Agroforestry for Sustainable Production: Economic Implications. Commonwealth Science Council, London, pp. 243-303.

[11] Boffa, J. M., Taonda B. J. S. and Dickey B. J. (2000). Field scale influence of karate (Vitellariaparadoxa) on sorghum production in the Sudan zone of Burkina Faso. Agroforestry C.

[12] Maitima et al, (2004). A methodological guide on how identify trends in the linkages between changes in land use, biodiversity and land degradation. LUCID Working Paper (No. 43). Nairobi, Kenya.
[13] Zomer et al. (2009). Trees on farm: analysis of global extent and geographical patterns of agroforestry. ICRAF Working Paper (No. 89) Kenya, Nairobi. World Agroforestry Center.

[14] Gardon, J. E., Hawthorne, W. D., Sandoval, G. and Barrance, A. J. (2003). Trees and farming in the dry zone of southern Honduras II: the potential for tree diversity conservation. Agroforestry Systems 59: 107-117.

[15] GWARDO (2010). GinirWereda Agricultural and Rural Development Office basics data.

[16] Bandeira PF, Martorell CJ, Meave A, Caballero J (2005) The role of rustic coffee plantations in the conservation of wild tree diversity in the Chinantec region of Mexico. BiodiversConserv 14: 1225-1240.

[17] Tesfaye, A. (2005). Diversity in Homegarden Agroforestry systems of Southern Ethiopia. PhD thesis, Wageningen University, Netherlands.

[18] Abed, T. and Stephens, N. C. (2003). Tree measurement manual for farm foresters. Second edition, edited M. Parsons. National Forest Inventory, Bureau of Rural Sciences, Canberra.

[19] Scherret al. (1990). Building opportunities for small-farm agroforestry to supply domestic wood markets in developing countries. Agroforestry System, 61-62 (1-3), 357-370.

[20] Azene Bekele, (1993). Useful Trees and Shrubs of Ethiopia. Identification, Propagation, and Management for Agricultural and Pastoral Communities. Regional Soil Conservation Unit, Swedish International Development Authority. 473 pp.

[21] Hedberg, I. \& Edwards, S. (1989). Flora of Ethiopia, vol. 3. Addis Ababa and Asmara, Ethiopia, Uppsala, Sweden, 659 pp.

[22] Kent M, Coker P (1992). Vegetation Description and Analysis: A practical approach. Belhaven Press, London. p. 263.

[23] Diserud, O. H. and Odegaard, F. (2006) A Multiple-Site Similarity Measure. Biology Letters, 3, 20-22.

[24] Mesele, N. (2002). Socio economic aspects of farmers eucalypt plant practice in the enset coffee based agroforestry system of Sidama, Ethiopia: The case of Awassa and shebedino district Msc thesis, ISSN 1402-201X.

[25] Balcha, A. (2013). Plants used in material culture in Oromo community, Jimma, Southwest Oromia, Ethiopia. African Journal of Plant Science 7 (7): 285-299.

[26] Belay $\mathrm{T}$, et al (2014). Woody plant diversity in an Afromontane agricultural landscape Debark District, northern Ethiopia). Forests Trees and Livelihoods 23 (4): 261-279.

[27] Bajigo A, Tadesse M (2015). Woody Species Diversity of Traditional Agroforestry Practices in Gununo Watershed in Wolayitta Zone, Ethiopia. Forest Resource 4: 4.

[28] Motuma, T. el at (2008). Woody Species Diversity in a Changing Landscape in the South-Central Highland of Ethiopia. Agriculture, Ecosystems and Environment, 128, 5258. http://dx.doi.org/10.1016/j.agee.2008.05.001

[29] Abiot M, Gonfa K (2015). Woody Species Diversity in Traditional Agroforestry Practices of Dellomenna District, Southeastern Ethiopia: Implication for Maintaining Native Woody Species. International Journal of Biodiversity pp. $1-13$. 
[30] Tefera M, Mirutse G, Ensermu K (2015). Ethno-botanical study of homegarden plants in Sebeta-Awas District of the Oromia Region of Ethiopia to assess use, species diversity and management practices. Journal of Ethno-biology and Ethnomedicine 11 (64): 1-13.

[31] Mekonnen, E. L., Asfaw, Z. \&Zewudie, S. (2014). Plant species diversity of homegarden agroforestry in Jabitenan District, northwestern Ethiopia. International Journal of Biodiversity and Conservation, 6 (4), 301-307. doi: 10.5897/IJBC2014.0677.

[32] Etefa G, Raj AJ (2013). Assessment of biodiversity in cropland agroforestry and its role in livelihood development in dryland areas: A case study from Tigray region, Ethiopia. Journal of Agricultural Technology 9 (4): 829-844.

[33] Tola el at (2014). Balancing ecosystem services and disservices: smallholder farmers \& use and management of forest and trees in an agricultural landscape in southwestern Ethiopia. Ecology and Society 19 (1): 30.

[34] Abreha A, Gebrekidan W (2014). Woody Plant Inventory and Diversity in Traditional Agroforestry of Selected Peasant Association of South Gonder Zone, North West Ethiopia. Journal of Environment and Earth Science 4 (15): 2224-3216.
[35] Zebene et. al.,(2015). Plant Species Richness and Structure of Homegarden Agroforestry in Jabithenan District, NorthWestern Ethiopia. International Journal of Environmental Sciences Vol. 4 No. 2. 2015. Pp. 52-58.

[36] Megabit Beyene, Muktar Mohammed, LisaneworkNigatu.(2018). Plant Species Diversity and Structure in Homegarden Agroforestry Systems of Bulen District, North-Western Ethiopia. Agriculture, Forestry and Fisheries. Vol. 7, No. 6, 2018, pp. 121-132.

[37] Muktar, R. (2006). Farm characteristics and tree species diversity in Arbegona district, high lands of southern Ethiopia. MSc thesis report No. 2006: 83, 88 pp.

[38] Aklilu A, et al.(2013). Agroforestry Practices and Farmers' Perception in Koga Watershed, Upper Blue Nile Basin, Ethiopia.

[39] Simon S, Girma B (2004). Composition, structure and regeneration status of woody species in Dindin national forest, souse east Ethiopia: implication for conservation. Ethiopian Journal of Biological Science 3 (1): 31-48.

[40] Ewuketu L M, Zebene A, Solomon Z (2014). Plant species diversity of homegarden Agroforestry in Jabithenan District, North- western, Ethiopia. International Journal of Biodiversity and Conservation 6 (4): 301-307. 